Ahmad

Hussein Juma'h*

Universidad Interamericana de Puerto Rico, San Juan, Puerto Rico

Recibido: 30 de agosto de 2013

Concepto de evaluación: 10 de febrero de 2014

Aprobado: 17 de marzo de 2014

Artículo de reflexión

DOI: $h$ ttp://dx.doi.org/10.14718/ revfinanzpolitecon.2014.6.1.8

(C) 2014 Universidad Católica de Colombia. Facultad de Ciencias Económicas y Administrativas. Todos los derechos reservados.

*Ph. D., CPA, Professor of finance and accounting, DBA (Finance) coordinator, Metro Campus, InterAmerican University of Puerto Rico. Mail: Inter-American University of Puerto Rico, Apartado Apartado 191293, San Juan,

Puerto Rico 00919-1293. Mail: jumah@intermetro.edu
Finanz. polit. econ., ISSN: 2248-6046, Vol. 6, No. 1, enero-junio, 2014, pp. 159-168

Edición Especial - Economía Regional

\section{The Materiality Concept: Implications for Managers and Investors}

\section{ABSTRACT}

Discuss the implications of materiality of financial information on "earnings management". Imply the content description and analysis of FASB Accounting Standards Codification ${ }^{\mathrm{TM}}$. The Professional View is used to confirm the absence of materiality guidelines in the US GAAP. Materiality, importance and significance are terms used to indicate the materiality consideration in the Codifications. The main conclusions are concerned to, first, the internal and external determinants and motives influence the practices of "earnings managements", and second US GAAP do not offer well defined guidelines to apply materiality on decision making.

Keywords: Accounts Manipulation, Earnings Management, Materiality, and Financial Statements.

JEL: M00, M4

\section{El concepto de materialidad: implicaciones para gerentes e inversionistas}

\section{RESUMEN}

Se discuten las implicaciones de la materialidad de la información financiera sobre "manejo de los ingresos". Implica la descripción y el análisis del contenido de la Codificación de Normas Contables ${ }^{\mathrm{TM}}$. Las perspectivas profesionales fueron utilizadas para confirmar la ausencia de directrices de importancia relativa en los Principios de Contabilidad Generalmente Aceptados (en inglés, PCGA) de los EE. UU. Los términos "materialidad", "significancia" e "importancia" fueron usados para determinar la inclusión de materialidad en las codificaciones. Las principales conclusiones indican que, primero, los factores determinantes y las motivaciones internas y externas influyen en las prácticas de "manejos de ganancias" y, segundo, los PCGA de EE. UU. no cuentan con directrices bien definidas para aplicar la materialidad en la toma de decisiones.

Palabras clave: manipulación de cuentas, manejo de ingresos, materialidad, estados financieros. 


\section{O conceito de materialidade: implicações para os gerentes e investidores}

\section{RESUMO}

Discutem-se as implicações da materialidade da informação financeira sobre "gestão de ganhos". Implica a descrição e a análise do conteúdo da Codificação de Normas Contáveis ${ }^{\mathrm{TM}}$. As perspectivas profissionais foram utilizadas para confirmar a ausência de diretrizes de importância relativa nos Princípios de Contabilidade Geralmente Aceitos (em inglês, GAAP) dos Estados Unidos da América (EUA). Os termos "materialidade", "significância" e "importância" foram usados para determinar a inclusão de materialidade nas codificações. As principais conclusões indicam que, primeiramente, os fatores determinantes e as motivações internas e externas influenciaram nas práticas de "gestão de ganhos" e, segundo, os PCGA dos EUA não contam com diretrizes bem definidas para aplicar a materialidade na tomada de decisões.

Palavras-chave: Manipulação de contas, gestão de ganhos, materialidade, estados financeiros. 


\section{INTRODUCTION}

The current global financial crisis has influenced the investors' perceptions on the evaluation of companies' released information. The corporate' financial problems and scandals have increased and the financial problems are related to the manipulation of financial information (Elias, 2004, Chen et al., 2005, Noronha et al., 2008). The accountants' practices, in particular estimation of financial information and evaluating the materiality of the information to be included in the financial statements, are important to add an additional element to explain the relationship between the global financial crisis and earnings management. The differences between firms/auditors considerations and classifications of material information influence earning management and that in turn contribute to the financial crisis.

The concept of materiality is referred to the magnitude of an omission or misstatement of accounting information that probably influences the users of the financial statements (FASB Concepts Statement No. 2, 1980).

Accountants frequently use estimations to prepare financial reports. Different estimations make the comparability of financial data within or between companies very difficult task for the users of the financial statements. The materiality considerations are important for accountants' estimations. The application of materiality concept varies between accountants. Materiality applications influence the financial statements users with respect to the differentiation between "accounts manipulation" and "earnings management". A significant aspect of manipulations is the desire to smooth (maximize or minimize) reported income (Stolowy and Breton, 2003; Moore, 1973; Noronha et al., 2008).

In linking the materiality implications on accountants' decision making that involves earnings managements and the fairness of companies' information, the remaining of the article is organized as follows: the following section presents the differentiations between accounts manipulation and earnings management.
Second, perceptions, and motives for earnings management are discussed. Third, the aspects of auditing and regulatory enforcement controls are presented. Fourth, the relation between US GAAP and materiality concept is discussed and finally the main conclusions are included.

\section{ACCOUNTS MANIPULATION AND EARNINGS MANAGEMENT}

Accounts manipulation is defined as the discretion of managers to make accounting choices or to design transactions affecting the possibilities of transferring wealth between the company and the society (political costs), funds providers (cost of capital) or managers (compensation plans). In the first two cases, the firms may obtain benefits from the wealth transfer. In the third, managers are acting against the firms' interests (Stolowy and Breton, 2003).

The activities covered by the term "earnings management" normally remain within the law boundaries. Earnings manipulation activities exceeded from legitimate/legal activities to fraud or violating GAAP, with the intention to mislead some stakeholders about underlying economics and performance of a company. The terms of accounts manipulation and earnings management are differentiated based on the law's boundaries (Noronha et al., 2008).

Earnings management definitions also relate to the accounting guides: earnings management is the presentation of accounting numbers within scope of the GAAP. Creative accounting is defined as the process of intentionally exploiting the GAAP or the law to present financial statements according to the managements' interests, and to achieve a desired level of reported earnings". The earnings management activities are seen as a continuum of purposeful interventions in the external financial reporting process from legitimate activities (Baralexis, 2004; Koumanakos et al., 2005; Guang et al., 2006; Noronha et al., 2008). In the following table, examples of earnings management and earnings manipulation/fraud are presented. 
Earning management versus Earning Manipulation/Fraud

\begin{tabular}{|c|c|c|c|c|c|}
\hline \multicolumn{3}{|c|}{ Earnings management } & \multicolumn{3}{|c|}{ Earnings manipulation/Fraud } \\
\hline $\begin{array}{c}\text { Innovations \& } \\
\text { increasing internal } \\
\text { efficiency }\end{array}$ & $\begin{array}{l}\text { Estimations } \\
\text { \& adopting } \\
\text { accounting } \\
\text { methods }\end{array}$ & $\begin{array}{l}\text { Managing accounts } \\
\text { for company's } \\
\text { interest }\end{array}$ & $\begin{array}{l}\text { Managing accounts } \\
\text { for manager's } \\
\text { interest }\end{array}$ & $\begin{array}{l}\text { Accounts \& events } \\
\text { manipulation }\end{array}$ & $\begin{array}{l}\text { Records' } \\
\text { falsifications }\end{array}$ \\
\hline $\begin{array}{l}\text { R\&D, new products, } \\
\text { patents, etc. }\end{array}$ & $\begin{array}{c}\text { Depreciation, } \\
\text { accruals estimations }\end{array}$ & $\begin{array}{l}\text { Dividend \& } \\
\text { repurchase signals }\end{array}$ & $\begin{array}{c}\text { Managing } \\
\text { announcements } \\
\text { dates }\end{array}$ & $\begin{array}{c}\text { Not disclosing } \\
\text { economic events on } \\
\text { time }\end{array}$ & $\begin{array}{l}\text { Altering company's } \\
\text { records }\end{array}$ \\
\hline
\end{tabular}

Source: Adopted from Baralexis, 2004; Koumanakos et al., 2005; Guang et al., 2006; Noronha et al., 2008.

\section{PERCEPTIONS AND MOTIVES OF EARNINGS MANAGEMENT}

Accounting academics have different perception of earnings management than do practitioners and regulators. The managerial incentives created by compensation contracts, regulatory motivates, capital market motivates etc. lead to earning management (Elias, 2004; Healy, 1985; Gaver et al., 1995; Noronha et al., 2008; Healy and Wahlen, 1998; Reverte, 2008).

Revealing relevant information is crucial for investors to evaluate a company's financial position (Fischer and Rozenweig, 1995; Sevin and Schroeder, 2005). How to perceive events as earnings management or earnings manipulation are important issues for investors (Chen et al., 2005). The share prices may reflect a risk premium that is associated with earnings variability. Managers can reduce the cost of capital and increase share prices by reducing earnings variability (Kanagaretnam et al., 2004).

The cases of earnings manipulation increase over years and refocus the attention on the manipulations of financial statements' content. It is noted that unethical earnings management behavior can be attributed to the failure of corporate ethics. The firm's ethical values contribute to the development of earnings management and manipulation behaviors.

The corporate ethical values are important determinants of earnings management perception. CPAs employed in organizations with high ethical values were more likely to view earnings mana- gement actions as unethical compared to CPAs in organizations with low values. In industry, CPAs view their organizations to have significantly lower ethical values compared to CPAs in public accounting and academia (Elias, 2004, Levitt, 1998).

There is no clear consensus in the accounting profession regarding their ethical acceptability of earning management. The debate on ethical acceptability of earnings management actions intensified after the revelation of their negative consequences on the fairness of the financial statements (Dechow and Skinner, 2000).

CEO wealth sensitivity is positively associated with abnormal accrual usage and the relation is consistent with income smoothing (Weber, 2006). Performance expectation is important in conducting an audit because people try to validate their perceptions of reality no matter if they perceive an event incorrectly. Performance evaluation depends on the perceptual process and the performance expectations.

\section{ENFORCEMENT POWERS}

Reforms set forth in Sarbanes Oxley (SOX) and the NYSE, AMEX, and NASDAQ are designed to prevent the reoccurrence of corporate collapses at companies such as Enron Corp., WorldCom Inc., Ahold, and Global Crossing Ltd (Kanagaretnam et al., 2004).

The considerable amount of regulatory attention given to corporate governance issues in recent years suggests that stronger governance mechanisms would reduce opportunistic 
management behavior, thus improving the quality and reliability of financial reporting. Regulators believe that this in turn will help to maintain and enhance investors' confidence in the integrity of capital markets (Niu, 2006).

The corporate scandals after the case of Enron raised concerns about audit quality even among larger sized accounting firms, which are normally considered the premier accounting firms and associated with higher audit quality. Audit quality research has focused primarily on differences between larger-sized firms and smaller-sized firms (Chen et al., 2005).

The adequacy of auditors' works to manage control force against earnings management has recently received much attention (Johl et al., 2007). The control forces are related to the effect of audit committee independence on the outside auditor choice, and on external auditor's effectiveness and financial reporting quality (Ebrahim, 2007).

Earnings management is related to the size of the board of directors. This supports the view that larger boards appear to be ineffective in their oversight duties relative to the smaller boards. The relation between measures of earnings management and both institutional ownership in the firm and quality of its outside audit is assumed consistent and negative (Ebrahim, 2007; Rahman and Ali, 2006).

Auditors play a significant role in mitigating the earnings manipulative behavior. They found that earnings management is pervasive in the quarterly earnings numbers. For example, there are more zeros and fewer nines in the second digit of the earnings number in each of the four quarters. Also, the earnings management in the fourth quarter, while still prominent, but is less as compared to each of the first three quarters (Guang et al., 2006).

The ability to manage earnings under the integral approach to interim reporting, however, decreases as the fiscal year progresses. The integral approach to quarterly financial reporting provides firms with more opportunity to manage earnings in the earlier quarters during any fiscal year. Since only the fourth quarter is audited, if the auditor was able to ensure that the firm complies with the requirements of the integral approach, the firm's ability to engage in earnings would be diminished in the fourth fiscal quarter (Guang et al. , 2006; Coté and Qi, 2005).

\section{MATERIALITY IMPLICATIONS ON EARNINGS' MANAGEMENT}

The materiality concept influences accountants' decision making, in particular decisions requiring estimations. The information considered immaterial by accountants is not reported to investors, creditors, and other users of financial statements. The stakeholders are aware of all public information (mandatory or non-mandatory information), and investors give attention to the released no-mandatory information (Watts and Zimmerman, 1986).

The concept of materiality is simple but it is central in applying GAAP. FASB Concepts Statement No. 2, Qualitative Characteristics of Accounting Information (1980) defines materiality as follows:

The magnitude of an omission or misstatement of accounting information that, in the light of surrounding circumstances, makes it probable that the judgment of a reasonable person relying on the information would have been changed or influenced by the omission or misstatement. (Para. 132)

Accounting authorities do not offer specific guide of materiality and less than $10 \%$ of the pronouncements offer specific measurements of materiality. The economic factors are considered to determine the materiality of any issue. A rough criterion of $5 \%$ to $10 \%$ of net income is an example of an adapted guideline of materiality by some CPAs (Patterson, 1967). Other basis of measures such as income trend or income growth has been used. Auditors usually use three quantitative measurements, namely percentage effect on net income, percentage effect on total sales or total revenues, and percentage effect on total assets (Thompson, 1993; Thompson et al., 1990; Kinney, 1986). 


\section{FASB ACCOUNTING STANDARD CODIFICATION $^{\mathrm{TM}}$}

The FASB Accounting Standards Codification ${ }^{\mathrm{TM}}$ Professional View (the Codification) provided by Financial Accounting Foundation (FAF) and the American Accounting Association (AAA) enable us to identify keywords related to materiality concept in accounting practices. To identify the materiality indications in the Codification, we use the keywords: materiality, importance and significance or some of these words derivations such as material, important, significant. From the listed codifications on the year 2010, only 95 indicate some implications of materiality. These are less than $10 \%$ of the codifications (consistent with Thompson, et. al., 1990). The following table summarizes the count and the percentage of each keyword.

\begin{tabular}{|c|c|c|c|c|}
\hline Keyword & Significance & Importance & Materiality & Total \\
\hline Count & 58 & 16 & 21 & 95 \\
\hline Percentage & $61 \%$ & $17 \%$ & $22 \%$ & $100 \%$ \\
\hline
\end{tabular}

The followings are examples of codifications that include materiality concept without guidelines or bases to determine the importance, significance or materiality of the discussed issues.

"... If continuing cash flows are generated, the determination as to whether those continuing cash flows are direct or indirect should be based on their nature and significance..." 205 Presentation of Financial Statements > 20 Discontinued Operations $>55$ Implementation Guidance and Illustrations.

"... In view of the fact that policies listed under these items are fundamental policies which cannot be changed without prior shareholder approval, the importance of adopting a clear policy with regard to such investments is apparent. The prospectus of a registered investment company should also fully disclose the company's policy with respect to restricted securities..." 946 Financial Services - Investment Companies > 320 Investments - Debt and Equity Securities > S99 SEC Materials.

"...of an analysis of materiality; it cannot appropriately be used as a substitute for a full analysis of all relevant considerations. Materiality concerns the significance of an item to users of a registrant's financial statements. A matter is "material" if there is a substantial likelihood that a reasonable person would consider it important..." 250 Accounting Changes and Error Corrections > 10 Overall > S99 SEC Materials.

Some codifications (e.g. 225, 310 and 323) explain the use of a percentage (e.g. 10\%) as guidelines or bases for the materiality determination.

"...The assessment of materiality is the responsibility of each registrant. However, absent concerns about trends or other qualitative considerations, the staff generally will not insist on the reporting of income or loss applicable to common stock if the amount differs from net income or loss by less than ten percent..." 225 Income Statement $>10$ Overall > S99 SEC Materials.

“...relating to properties underlying any loans ... except that in the determination of significance the $20 \%$ disclosure threshold should be measured using total assets..." 310 Receivables $>$ 10 Overall > S99 SEC Materials.

"...significance tests of Rule 1-02(w)? Interpretive Response: The $10 \%$ measurement level of the significant subsidiary rule was not intended to establish a materiality criteria for omission, and the arbitrary exclusion of summarized information for selected entities up to a $10 \%$ level is not appropriate..." 323 Investments-Equity Method and Joint Ventures $>10$ Overall > S99 SEC Materials.

In rare cases the codifications indicate a specific percentage as a level of significance. The Code 944 explains the bases for the materiality of insurance with respect to inclusion as a note to financial statements. The Code 815 explains the use of a percentage (e.g. $5 \%$ or $10 \%$ ) to indicate the level of significance in determining the materiality implications.

"...the amount of which is in excess of five percent of total liabilities. State in a note to the financial statements the relative significance of participating insurance expressed as percentages of (1) insurance in force and (2) premium income; and the method by which earnings and dividends 
allocable to such insurance is determined..." 944 Financial Services-Insurance $>210$ Balance Sheet $>$ S99 SEC Materials.

"...an entity shall evaluate, in part, the significance of the estimated costs of converting the asset to cash in determining whether those assets are readily convertible to cash. 15-126 For purposes of assessing significance of such costs, an entity shall consider those estimated conversion costs to be significant only if they are 10 percent or more of the gross sales..." 815 Derivatives and Hedging $>10$ Overall $>15$ Scope and Scope Exceptions.

\section{CONCLUSIONS}

Accountants frequently use estimations to report financial results, conditions, and performance for their companies. The materiality concept is essential for any estimation in all decision making. The existence of information asymmetry between management and shareholders is a necessary condition for earnings management. This is because shareholders cannot perfectly determine a firm's performance and prospects in an environment in which they have less information than management. In such an environment, management can use its flexibility to manage reported earnings. Also, management's discretionary ability to manage earnings increases as the information asymmetry between management and shareholders increases.

Based on agency theory, issues associated with the separation between ownership and control will lead managers (agents) to act in an opportunistic manner by increasing their personal wealth at the expense of the owners (principal) of an organization (Jensen and Mackling, 1976; Abdul and Haneem, 2006).

When managers are concentrated on the company's goals and motivated toward achieving those goals, it is highly expected that the company achieve its goal. However if managers are working to achieve their own objectives and do not work to maximize companies wealth, the company is expected to have difficulties in achieving its goals.
The internal factors and external factors related to the case context influence accountants' views and perceptions. Examples of external factors include political, economic, and cultural issues that may influence the perception of accountants with respect to a decision making.

The internal factors are those under the individual's control and external factors are concerned to the situation and the individual may be force to act. This determination of the internal and external factors depend on three factors: 1) distinctiveness where the individual act differently under different situations, 2) consensus is referred to the behavior of all individuals is the same way in the same situation, and 3) consistency referred to the behavior of an individual is the same over time for similar situations.

Rigorous regulations cannot completely remove earnings management from the market, but it can probably reduce it and provide explicit evidence for detecting and penalizing earnings management behaviors. The lack of a systematic framework of accounting standards brings many opportunities for earnings management (Noronha, et al., 2008).

Governance practices, especially independent boards and committees, effective management compensation, and powerful shareholders are important in constraining management from managing earnings and in ensuring a higher quality of earnings (Niu, 2006).

Accountants themselves, the users of financial accounting, generally accepted accounting principles, and the environment are the main factors that influence the perception of the preparers and the users of financial statements.

In a turbulent political status, accountants may become more cautious than in a stable political status. Accountants in a boom economy may perceive events in different way as in a recession economy. People in different cultures see things differently. Therefore, accountants depend on somehow on their culture and the environment in which they work.

The complexity and the time required versus the time available to solve any issue are important 
factors. Also, individuals involved and or related to the decision influence accountants in their works. Personal attitudes, motivations, interests, education, experience, and expectations are the main factors that influence the perception of accountants, auditors, managers, and investors in considering the materiality of the relevance of an event or a transaction.

Auditors normally conduct most of their works judging others' work. Therefore, auditors' perception on the adequacy of accounting data is important. People in general selectively interpret what they see based on their interest, experience and attitudes. In the same way auditors perceive an event based on their interest, experience, education. How auditors believe about an event may influence their decision about the adequacy of such event.

Also, how other auditors perceive such an event is important and influences the decision of auditors in evaluating a company's data. Auditors may judge an event based on a single instance. For example if they found a material error in a transaction then they may decide to reevaluate the complete data. The type of organization and the industrial classification is another factor that may influence the decision of auditor in determining the materiality of an event.
In estimating the performance of companies' units, the absence of clear materiality judgment perhaps enables accountants to decide differently on same materiality situation. The perception of the users of financial statements influences the perception and expectations of accountants and auditor in their decision making. Accountants may consider an event as immaterial because most investors consider the same event as immaterial.

Earnings management has been studied in a variety of contexts, for example compensation contract, debt covenants, seasoned equity and initial public offerings. Some accounting research has examined the relationship of different corporate governance factors to different financial reporting issues. This includes financial reporting misstatements, fraud and earnings management (Dechow, et al., 1996; Ebrahim, 2007).

There is a scarcity to study the techniques used to manipulate companies' accounts (Stolowy and Breton, 2003). Also, there is a need to study earning management in relation to corporate control contests (Ben-Amar and Missonier-Piera, 2008) and it is important to realize more research with respect to application of materiality and its relation to earnings managements and accountants' estimations for companies' financial results and conditions. 


\section{REFERENCES}

1. Baralexis, S. (2004). Creative accounting in small advancing countries: the Greek case. Managerial Auditing Journal, 19(3), 440-461.

2. Ben-Amar and Missonier-Piera. (2008). Earnings management by friendly takeover targets. International Journal of Managerial Finance, 4(3), 232-243.

3. Chen, K., Lin, K. and Zhou, J. (2005). Audit quality and earnings management in Taiwan IPO firms. Managerial Auditing Journal, 20(1), 86-104.

4. Coté, D. and Qi, R. (2005). Honest EPS: a measure of GAAP earnings relative to pro forma earnings. International Journal of Managerial Finance, 1(1), 25-35.

5. Dechow, P. M. and Skinner D. (2000). Earnings management reconciling the views of accounting academics, practitioners, and regulators. Accounting Horizon, 14( 2), 235-250.

6. Dechow, P., Sloan, R. and Sweeney, A. (1996). Causes and consequences of earnings manipulations: An analysis of firms subject to enforcement actions by SEC. Contemporary Accounting Research, 13(1), 1-36.

7. Ebrahim, A. (2007). Earnings management and board activity: An additional evidence. Review of Accounting and Finance, 6(1), 42-58.

8. Elias, R. (2004). The impact of corporate ethical values on perceptions of earnings management. Managerial Auditing Journal, 19(1), 84-98.

9. Financial Accounting Foundation and American Accounting Association (FASB). (s. f.). Codification to Accounting Faculty and Students. Retrieved from http://aaahq.org/FASB/ Access.cfm.

10. Financial Accounting Standards Board (FASB). (1980). Qualitative characteristics of accounting information. In Statement of Financial accounting Concepts No. 2. Stamford, CT: FASB.

11. Fischer M., and Rozenweig, K. (1995). Attitudes os students and accounting practitioners concerning the ethical acceptability of earnings management. Journal of Business Ethics, 14 433-444.

12. Gaver, J., K. M. and Austin, J.R. (1995). Additional evidence on bonus plans and income management. Journal of Accounting EB Economics, 19(1), 3-28.

13. Gaver, J. J. and Paterson, J.S. (2001). The association between external monitoring and earning management in the property-casual insurance industry. Journal of Accounting Research, $39(2), 269-282$.

14. Guang, L., He, D. and Yang, D. (2006). Auditing, integral approach to quarterly reporting, and cosmetic earnings management. Managerial Auditing Journal, 21 (6), 569-581.

15. Healy, P. M. (1985). The effect of bonus schemes on accounting decisions. Journal of Accounting and Economics, 7, 85-107.

16. Healy, P. M. and Wahlen, J. M. (December, 1999). A review of the earning management literature and its implications for standard setting. Accounting Horizons, 13(4), 363-365.

17. Jensen, M. and Meckling, W.H. (1976). Theory of the firm: managerial behavior, agency costs, and ownership structure. Journal of Financial Economics, 3(4), 305-360.

18. Johl, S., Jubb, C. and Houghton, K. (2007). Earnings management and audit opinion: evidence from Malaysia. Managerial Auditing Journal, 22 (7), 688-715.

19. Kanagaretnam, K., Lobo, G. and Mathieu, R. (2004). Earnings management to reduce earnings variability: Evidence from bank Loan loss provisions. Review of Accounting and Finance, 3(1), 128-148. 
20. Kinney, W. (1986). Audit technology and preferences for auditing standards. Journal of Accounting and Economics, 8(1), 73-89.

21. Koumanakos, E., Costas, S. and Georgiopoulos, A. (2005). Firms acquisition and earnings management: evidence from Greece. Managerial Auditing Journal, 20(7), 663-678.

22. Levitt, A. (1998). The numbers game. The CPA Journal, 68, 14-19.

23. Moore, M. L. (Spring 1973). Management changes and discretionary accounting decisions. Journal of Accounting Research, 11(1),100-107.

24. Niu, F. (2006). Corporate governance and the quality of accounting earnings: a Canadian perspective. International Journal of Managerial Finance, 2(4), 302-327.

25. Noronha, C., Zeng, Y. and Vinten, G. (2008). Earnings management in China: an exploratory study. Managerial Auditing Journal, 23(4).

26. Patterson, R. G. (October, 1967). Materiality and the economic environment. The Accounting Review, October, 772-774.

27. Rahman, R., Abdul, R. and Ali, M. H. F. (2006). Board, audit committee, culture and earnings management: Malasyan evidence. Managerial Auditing Journal, 21 (7), 783-804.

28. Reverte, C. (2008). Institutional differences in EU countries and their relationship with earnings management differences: Implications for the pan-European stock market. Journal of Accounting and Organizational Change, 4(2), 182-200.

29. Sevin, S. and Schroeder, R. (2005). Earnings management: Evidence from SFAS No. 142 Reporting. Managerial Auditing Journal, 20(1), 47-54.

30. Stolowy, H. and Breton, G. (2003). Accounts manipulation: A literature review and proposed conceptual framework. Montreal: University of Quebec, Montreal and HEC Mgmt. School.

31. Thompson, J.H. (March,1993). Quantitative guidelines: Guidance based on professional pronouncements. The CPA Journal, 63(3)48-52.

32. Thompson J.H., Hodge, T.G. and Worthington, J.S. (July, 1990). An inventory of materiality guidelines in accounting literature. The CPA Journal, 60(7), 50.

33. Watts R.L. and Zimmerman, J.L. (1986). Positive accounting theory. Englewood Cliffs, NJ: Prentice-Hall

34. Weber, M. (2006). Sensitivity of executive wealth to stock price, corporate governance and earnings management. Review of Accounting and Finance, 5 (4), 321-354. 